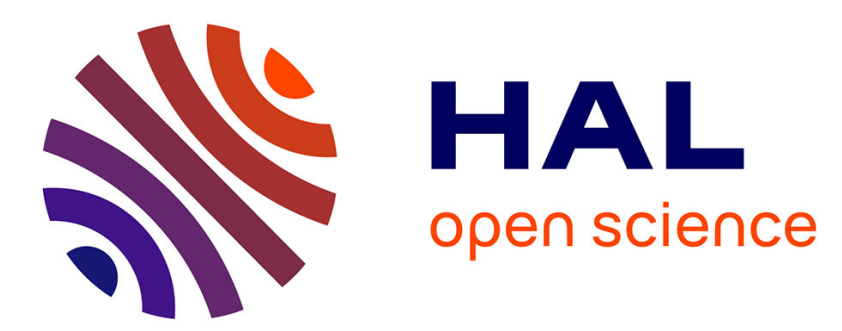

\title{
MICROENGINEERING - THE NEW APPLICATION OF CHEMICAL VAPOR DEPOSITION
}

\author{
P. Grabiec, J. Lysko
}

\section{To cite this version:}

P. Grabiec, J. Lysko. MICROENGINEERING - THE NEW APPLICATION OF CHEMICAL VAPOR DEPOSITION. Journal de Physique IV Proceedings, 1991, 02 (C2), pp.C2-897-C2-901. 10.1051/jp4:19912107 . jpa-00249785

\section{HAL Id: jpa-00249785 https://hal.science/jpa-00249785}

Submitted on 1 Jan 1991

HAL is a multi-disciplinary open access archive for the deposit and dissemination of scientific research documents, whether they are published or not. The documents may come from teaching and research institutions in France or abroad, or from public or private research centers.
L'archive ouverte pluridisciplinaire HAL, est destinée au dépôt et à la diffusion de documents scientifiques de niveau recherche, publiés ou non, émanant des établissements d'enseignement et de recherche français ou étrangers, des laboratoires publics ou privés. 
Colloque C2, suppl. au Journal de Physique II, Vol 1, septembre 1991

\title{
MICROENGINEERING - THE NEW APPLICATION OF CHEMICAL VAPOR DEPOSITION
}

\author{
P.B. GRABIEC and J.M. LYSKO \\ Inst. of Electron Technology, al. Lotnikow 32/46, 02-668 \\ Warsaw, Poland
}

\begin{abstract}
Abetract - Techniques of Chemical Vapour Deposition, developed primarily for VLSI Circuits fabrication, enriched by the experience of CVD methods utilized in the field of hard wear resistant coatings and other mechanical related application, are the versatile tools enabling creation of complex, $\quad$-dimensional microstructures requimed for development of micromechanical devices - sensors and actuators. In this paper the application of CVD methods for fabrication of micromectianic and other transducers technologicaliy microelectronic compatible is discussed. An example of capacitive pressure sensor which can be integrated with cmos devices is presented.
\end{abstract}

1. Introduction.

Up to now transducers have been mainly fabricated by the use of conventional fine mechanics. This is a limiting factor for the further system integration with respect to miniaturization, weight, power consumption, performance and price.

Mieromechanics is a discipline which evolved out of the advanced integrated circuits manufacturing. While the standard IC technology solely exploits the electrical properties of silicon, dielectrics and metals, micromechanics introduces a mechanical element into the device performance. In addition. other physical and chemical properties of materials can be utilized to develop sensor structures. All the well known advantages of the silicon technology, such as precision, reliability, repeatability, miniaturization, high productivity and cost effectiveness apply also here.

2. Micromechanical materials and processing.

The basic material applied in silicon micromechanics is of course silicon itself. Mechanical properties of monocrystalline silicon are surprisingly good as compared to that of typical construction material - stainless steel (see table below). Also, materials widely used in VLSI IC processing such as SiOz, doped SiOz, SizN4, Al, W, Mo can be utilized as well. Due to their advantageous mechanical properties, some hard wearing resistant materials as TiC. SiC or diamond are also considered. 
TABle 1. mechanical properties of some micromechanics materials [1]

\begin{tabular}{|c|c|c|c|c|}
\hline Material & $\begin{array}{c}\text { Yield } \\
\text { Strength } \\
\text { dyne } / \mathrm{cm}^{2} \\
* 10^{10}\end{array}$ & $\begin{array}{l}\text { Knoop } \\
\text { Hardness } \\
\text { kg/mm }\end{array}$ & $\begin{array}{l}\text { Young } \\
\text { modulus } \\
\text { dyne } / \mathrm{cm}^{2} \\
* 10^{12}\end{array}$ & $\begin{array}{l}\text { Density } \\
8 / \mathrm{cm}^{3}\end{array}$ \\
\hline di amond & 5.3 & 7000 & 10.35 & 5.5 \\
\hline SiC & 21 & 2480 & 7.0 & 3.2 \\
\hline $\mathrm{Si}_{3} \mathrm{~N}_{4}$ & 14 & 3486 & 3.85 & 3.1 \\
\hline $\sin _{2}$ & 8.4 & 820 & 0.73 & 2.5 \\
\hline$S i$ & 7.0 & 850 & 1.9 & 2.5 \\
\hline$w$ & 4.0 & 485 & 4.1 & 19.3 \\
\hline St.St. & 2.1 & 660 & 2.0 & 7.9 \\
\hline Al. & 0.17 & 150 & 0.70 & 2.7 \\
\hline
\end{tabular}

The ereation of micromechanical devices consist of various steps, the most important of which is a sequence of thin laver deposition. fine lithography patterning and etching. The key technological issue is the proper choice of the thin layer material and etching method, to ensure required etching selectivity, with regard to different components of the device structure, necessary to create such complex 3-D structures. An important advantage of Chemical Vapour Deposition as compared with other methods is the variety of materials which could be deposited using this technique and the ready control of the properties of the deposited material by means of doping during deposition. In this way, depositing materials etchable and etch resistant in appropriate sequence, and using standard photolithography patterning methods bridges, membranes, springs, cantilevers and many other complex three dimensional structures can be created. An important advantage of many CVD techniques, especially plasma assisted, is low process temperature resulting in thermal induced stress reduction. Below, is a list of materials which can be deposited by means of CVD methods. 
TABle 2. Chemically deposited Material.s, $[2,3]$

INSULATORS: $\mathrm{SiO}_{2}, \mathrm{Al}_{2} \mathrm{O}_{3}, \mathrm{TIO}_{2}, \mathrm{Ta}_{2} \mathrm{O}_{5}, \mathrm{Si}_{3} \mathrm{~N}_{4}, \mathrm{EN}, \mathrm{SIN}_{x} \mathrm{O}_{y}, \mathrm{FSG}$, BFSG, ASSG, ZnO, ZrO, ZnS

SEMICONDUCTORS : Si, poly-Si, a-Si, Ge, diamond, GaAs, GaF, AlN, AlF, GaN, InF, InAsF, GaInAsF,

CONDUctors : W (blant:), W (selective), Mo, Al, $\mathrm{Cr}, \mathrm{Ni}, \mathrm{Ta}, \mathrm{WSi} z^{\prime}$ TiSi, Tasi, Mosi, Cu, Zr, Fd, Ft, Ag, Au, Sn,

SUPERCONDUCTORS : $\mathrm{YEa}_{2} \mathrm{Cu}_{3} \mathrm{O}_{7-x}$

MAgNetics : Ga:YIE, GdIG, Fe $\mathrm{F}_{3}, \mathrm{Y}_{5} \mathrm{Fe}_{5} \mathrm{D}_{12}$

In spite of the variety of the deposition processes available, those developed for integrated circuits technology are utiliaed mainly in micromechanics. This is due to the fact that for these materials suitable etching methods have been mastered, ensuring the necessary precision, selectivity and, if necessary, anisotropy. A typical selection is: epitaxial silicon layers doped with phosphorous or with boron. LFCVD or FECVD deposited silicon nitride and polysilicon layers and boron and for phosphorous doped $5_{i 0}$ glass deposited using a variety of CVD methods.

The epitaxial silicon layers are utilized to produce thin membranes by electrochemical etching which stops at the epitaxial pn-junction. A similar effect could be achieved by chemical etching in ethylenediamine $\mathrm{CNH}_{2}\left(\mathrm{CH}_{2}\right)_{2} \mathrm{NH}_{2} \mathrm{H}^{2}$ - water - pyrocatechol $\mathrm{CC}_{6} \mathrm{H}_{4}(\mathrm{OH})_{2}{ }^{2}-$ pyrazine $\mathrm{CC}_{4} \mathrm{H}_{4} \mathrm{~N}_{2}{ }^{3}$ mixture which show significant reduction of heavily E-doped silicon etching rate.

Both $\mathrm{Si}_{5} \mathrm{~N}_{4}$ and $\mathrm{SiO}_{2}$ are used as dielectric or passivation 1 ayers or as the construction elements of a device structure. The S-dimensional structuring of these materials could be achieved due to the good selectivity of etching in a typical nitride etchant $\mathrm{H}_{3} \mathrm{FO}_{4}$ as well as in HF based Sioz etchants.

In the case of both $\mathrm{SiO}_{2}$ and poly-si layers doping with boron or phosphorous could be used to control the etching rate [4].

It should be noted, that to develop the design and technology of micromechanical device a good knowledge of available material and processing features and performance is necessary, so that some engineering tricks could be used to achieve the desirable goal. An example would be a poor penetration of the reactants, resulting in poor conformity of atmospheric pressure deposited $\mathrm{SiO}_{2}$ or pSE layers. This phenomenon can be utilized to clog a cavity, created by selective etching of PSG placed beneath silicon nitride or oolvsilicon laver. 
3. A CVD based capacitive silicon pressure sensor [5]

Silicon capacitive pressure sensors have been well finown for at least 10 years [0,7]. However, the constructions are lsual1y based on difficult two-side wafer etching, silicon to glass plate fusion sealing etc. Besides, integration of such process with IC processing is difficult. Lse of CVD methods allows the design of a pressure sensor avoiding such problems.

Fig. 1 presents cross-section of a capacitive pressure sensor. An inmovable capacitor electrode (2), and the conductive path (3) are formed in the p-type silicon substrate (1) by the phosphorous doping. These elements are contacted with the bonding pad (4) through the contact hole (5) in the phosphosilicate glass FSG (G). A movable capacitor electrode (7) and the conductive path (8) are formed by an aluminum layer (doped polysilicon was applied in some versions as well). The electrode (7) is deposited on the thin silicon nitride diaphragm (9) over the diffusion region. The electrode (7) is connected with the second bonding pad. The diaphragm (9) consist of the two LFCVD silicon nitride layers (10) (11). Its edges are stiffened by the thick polysilicon frame (12). The cavity (13) of the sensor is closed between the silicon substrate (1) the diaphragm ( 9 ) and, in the penetration region ( 14 ), by the PSG layer (b). A penetration region is a hole in the polysilicon layer (12) and silicon nitride layers (10). (11) 1 it is used to remove sacrificial FSG layer from the cavity (1引) during the fabrication sequence. The shape and the dimensions of the cavity are almost the same as for the sacrificial fSG layer. The penetration region (14) is located at the same side of the substrate (1) as the diaphragm. To provide some kind of mechanical protection, the whole capacitor with diaphragm is located in a $1.5 \mu_{m}$ deep trench in the substrate.

The whole sensor fabrication is based on one-sided wafer processing as in common integrated circuits technologies. The formation of sensor cavity is based on the coincidence of a two phenomena, the first, good selectivity of. FSG and silicon nitride etching in diluted $\mathrm{HF}$, and the second, AFCVD poor deposition kinetics inside cavities. For typical cell dimensions (electrode area $50 * 504 m$. separation $0.5 \mu \mathrm{m})$ the maximum capacitance change is 41 fF to 590 fF. 
C2-901

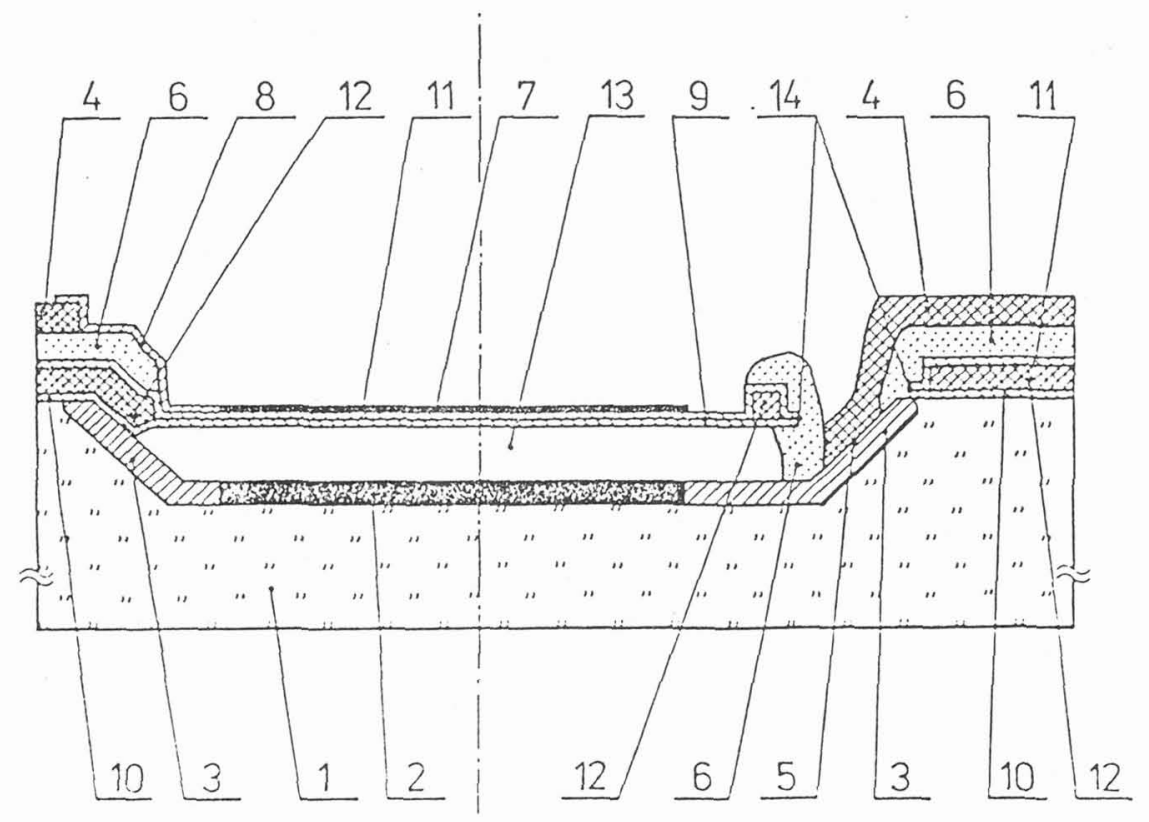

Fig.1. Cross-section of a capacitive pressure sensor.

1. Fetersen K.E., Froc. of the IEEE, 5 (1982) 420

2. Levy F.A., Microelectronic Materials and Frocesses, KLUWER PUIDI. $1989,0.203$

3. Suhr H., Bald J. et al., Froc. of the EURO-CVD-SEVEN, Les Editions de Fhysique, p. Cs-739

4. Grabiec F.B., Fietruszko S.M., ibid, p. Cs-58s

5. Lysko J.M., Stolarski E., Jachowicz R.S., Capacitive Silicon Fressure Sensor Eased on the One-Side Wafer Frocessing, will be presented on TFANSDUCERS:91 Conf., San Francisco 1991

6. Chau H.L., Wise K.D., IEEE Trans. El. Dev., 12 (1988) 2555

7. Ko W.H., Sensors and Actuators, 10 (1986) 303 